Review of

ECONOMICS

and

INSTITUTIONS
Review of Economics and Institutions

ISSN 2038-1379 DOI 10.5202/rei.v6i1.177

Vol. 6 - No. 1, Winter-Spring 2015 - Article 1

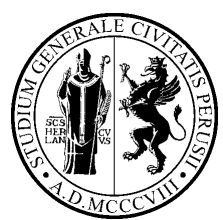

www.rei.unipg.it

\title{
Business groups in Emerging Economies: Introduction to the Special Issue
}

\author{
Fulvio Castellacci ${ }^{\bowtie}$ \\ Ishtiaq Pasha Mahmood \\ TIK Centre, University of Oslo \\ National University of Singapore, \\ Business School
}

\begin{abstract}
The existence, ubiquity and remarkable dynamics of business groups in emerging markets has stimulated a large amount of research, which has investigated the reasons for the emergence of groups, their ownership structure, their differentiation and vertical integration patterns, and their economic performance. However, there is still more limited evidence about business groups' strategies, i.e. how groups organize their business activities and what makes them more (or less) successful than independent enterprises. This Special Issue collects new research on economic groups network and internationalization strategies.
\end{abstract}

JEL classification: D22; D23; F14; F23 M21

Keywords: business groups, small businesses, portfolio entrepreneurs, ownership, diversification

${ }^{\boxplus}$ Corresponding Author. Address: TIK Centre, University of Oslo, Postboks 1108, Blindern, 0317, Oslo - Norway (Phone: +420 210310 232. Email: fulvio.castellacci@tik.uio.no).

\section{Recommended Citation}

Castellacci, F., Mahmood, P.I. (2015). Business Groups in Emerging Economies: Introduction to the Special Issue. Review of Economics and Institutions, 6(1), Article 1. Doi:10.5202/rei.v6i1.177. http://www.rei.unipg.it/rei/article/view/177 


\section{Introduction}

Business groups permeate emerging economies. A business group can be defined as "a set of firms which though legally independent, are bound together by a constellation of formal and informal ties and are accustomed to taking coordinated action" (Khanna and Rivkin, 2001, p. 47). The existence, ubiquity and remarkable dynamics of business groups in emerging markets has stimulated a large amount of research, which has investigated a number of related topics such as the reasons for the emergence of groups, their ownership structure, their differentiation and vertical integration patterns, and their economic performance (Khanna and Yafeh, 2007). The existing literature provides a rich and thorough characterization of business groups and their importance for economic development (Colpan et al., 2010). However, while there exist several studies focusing on the financial and economic performance of groups, there is still more limited evidence about their structure and strategies, i.e. how groups organize their business activities and what makes them more (or less) successful than independent enterprises (Carney et al., 2011). Further, another theme that is attracting increasing attention in this literature and that calls for future research is how business groups' strategies and performance are affected by the institutional context in which these firms operate. Many developing economies are currently undergoing a process of institutional change and transition that is commonly referred to as market development (CuervoCazzura and Dau, 2009). Market development may be defined as "the degree to which market-oriented institutions such as capital markets, legal systems, labor markets, and commercial value chains are present in support of business activity" (Chakrabarti et al., 2011, p. 7). How does this process of institutional change and market development affect business groups' performance and strategies? A traditional and well-established view - the so-called institutional voids thesis - contends that business groups in emerging economies are paragons: they play an important function for economic development by making up for missing or inefficient institutions, hence filling institutional voids (Leff, 1978; Khanna and Palepu, 1997). Thus, groups originate and prosper when national institutions are weak and, correspondingly, group performance is relatively better in countries characterized by weaker institutions than in economies with well-functioning institutional set ups (Mahmood and Lee, 2004; Khanna and Yafeh, 2007; Carney et al., 2011). On the other hand, a different view argues that business groups are parasites for developing economies. They are strong oligopolistic producers that are capable of erecting entry barriers. They are also inefficient and rent-seeking organizations that create agency problems and capital misallocations. According to this second thesis, these group-related inefficiencies would tend to decrease when the quality of institutions improves over the development process. Therefore, it would be reasonable to expect group 
performance and capabilities to be relatively better in countries characterized by well-functioning institutions than in economies with weaker institutional set ups (Castellacci, 2015). The first paper in this special issue â by Khanna and Yafeh â provides a comprehensive and authoritative survey of this debate, and it is a reprint of the article originally published by the authors in the Journal of Economic Literature in 2007. This article points out a taxonomy of business groups and develops some major hypotheses and empirical evidence on the formation and dynamics of groups in different institutional contexts. The article concludes that business groups can act as paragons or parasites depending on the institutional and economic context in which they are embedded. In the concluding part of their work, Khanna and Yafeh also discuss directions for future research in this field, and point among other things to the need to carry out further investigations of the factors that determine the formation of business groups. This is precisely the topic of the second article of this special issue, where Iacobucci, Guzzini and Rosa investigate the formation and structure of business groups in the small business sector. This paper points out and contrasts two different perspectives a the financial and the organizational/entrepreneurial perspective â and develops two main hypotheses in relation to these contrasting theoretical views, one on capital and knowledge intensity required by the business, and the other on the entrepreneur's ownership of the business groups' companies. The results of this paper suggest that both of the perspectives are relevant to explain group formation and existence in the small business sector, but that the entrepreneurial perspective is more relevant to investigate the ownership structure of firms. In the third article of the special issue, Mahmood and Zhu examine how firm performance is driven jointly by individual firm-specific capabilities and the characteristics of networks in which firms are embedded. By using a rich dataset of business groups in Taiwan and adopting stochastic frontier estimation to measure firm capabilities, the paper finds that the value of a firm's capability is contingent upon the structure and the content of the intra-group network in which it is embedded. Specifically, the results indicate that a dense intra-group network is likely to make innovative capability more valuable, although this effect varies across different types of network ties. While a dense network of intra-group buyer-supplier ties and equity ties enhances the value of innovative capability, a dense network of intra-group directorship ties does not influence the efficacy of a firm's innovative capability. The next two papers in the special issue shift the focus from the formation and structure of business groups to their strategies in terms of internationalization. The article by Castellacci Focuses on groups' export strategies and performance, and it investigates whether the export intensity of business companies is greater for group-affiliated firms (GAFs) or for standalone firms (SAFs). The empirical analysis makes use of the World Bank Enterprise Survey for Latin American economies. The results show that GAFs have 
lower export intensity than SAFs. The work also finds that the difference between GAFs and SAFs' export intensity is much stronger in the service sectors, industries in which Latin American business groups have actively been investing in recent years. These results provide support to the groups as parasites theoretical view, which as noted above emphasizes the negative consequences that groups have for economic development. Finally, the fifth article in this collection focuses on business groups' FDI strategies and performance. Hassan's paper, presents an empirical analysis of the relationships between host-country economic institutions (property rights protection, corruption, taxation, business regulations, macroeconomic stability) and the outward foreign direct investment location decisions of multinational business groups from emerging economies in Central and Eastern Europe. The analysis is based on an extensive dataset of nearly 25,000 location decisions of about 1,000 multinational companies throughout the period 1995-2010. The results point out that the international relocation choices of multinational business groups is enhanced in countries characterized by lower degrees of corruption, lower tax burden and more efficient business regulations. The results also suggest that multinational business groups from emerging economies in Europe tend to invest more actively in countries that have more efficient institutions compared to those that characterize their home countries. 


\section{References}

Carney, M., Gedajlovic, E., Heugens, P., Van Essen, M., Van Oosterhout, J., 2011. Business Group Affiliation, Performance, Context, and Strategy: A meta-analysis. Academy of Management Journal 54, 437-460. doi:10.5465/AMJ.2011.61967812

Castellacci, F., 2015. Institutional Voids or Organizational Resilience? Business Groups, Innovation, and Market Development in Latin America. World Development 70, 43-58. doi:10.1016/j.worlddev.2014.12.014

Chakrabarti, A., Vidal, E., Mitchell, W., 2011. Business Transformation in Heterogeneous Environments: The Impact of Market Development and Firm Strength on Retrenchment and Growth Reconfiguration. Global Strategy Journal 1, 6-26. doi:10.1002/gsj.3

Colpan, A., Hikino, T., Lincoln, J., 2010. The Oxford Handbook of Business Groups. Oxford University Press, Oxford. doi:10.1093/oxfordhb/9780199552863.001.000

Cuervo-Cazzura, A., Dau, L.A., 2009. Promarket Reforms and Firm Profitability in Developing Countries. Academy of Mangement Journal 52, 1348-1368.

Khanna, T., Palepu, K., 1997. Why Focused Strategies may be Wrong for Emerging Markets. Harvard Business Review 75, 41-51.

Khanna, T., Yafeh, Y., 2007. Business Groups in Emerging Markets: Paragons or Parasites. Journal of Economic Literature XLV, 331-372. doi:10.1257/jel.45.2.331

Leff, N., 1978. Industrial Organization and Entrepreneurship in the Developing Countries: The Economic Groups. Economic Development and Cultural Change 78, 661-674. doi:10.1086/451052

Mahmood, I.P., Lee, C.Y. 2004. Business Groups: Entry Barrier-Innovation Debate Revisited. Journal of Economic Behavior and Organization 54, 513531. doi:10.1016/j.jebo.2002.12.003 